\title{
SEMANTIC PRIMES IN HISTORICAL LANGUAGES. THE IDENTIFICATION OF THE OLD ENGLISH EXPONENT FOR DO ${ }^{1}$
}

\author{
Raquel Mateo Mendaza \\ Universidad de La Rioja \\ raquel.mateo@unirioja.es
}

\begin{abstract}
This journal article follows the research line opened on the search for semantic primes' exponents in Old English within the frame of the Natural Semantic Metalanguage theory (Goddard 1997, 2012; Goddard and Wierzbicka 2002). The aim of this study is to complete the line of research on prime identification opened on the category Actions, events, movement, contact by establishing the Old English exponent of the prime DO. With this purpose, this paper discusses the adequacy of different $O E$ verbs as possible prime exponent on the basis of textual frequency, morphology, semantics and syntactic complementation. Relevant data of analysis have been retrieved mainly from the lexical database of Old English Nerthus, the Dictionary of Old English (Healey et al. 2018) and the Dictionary of Old English Corpus (Healey et al. 2009).
\end{abstract}

Keywords: Natural Semantic Metalanguage, semantic primes, historical linguistics, Old English, valency options.

1 This research has been funded through the project FFI2017-83360P. 
RAQUEL MATEO MENDAZA

\section{PRIMITIVOS SEMÁNTICOS EN LENGUAS HISTÓRICAS. IDENTIFICACIÓN DEL EXPONENTE EN INGLÉS ANTIGUO PARA DO}

RESUMEN. Este artículo continúa la línea de investigación basada en la búsqueda de exponentes de primitivos semánticos en inglés antiguo dentro del marco de la teoría del Natural Semantic Metalanguage (Goddard 1997, 2012; Goddard and Wierzbicka 2002). Este estudio tiene como objetivo completar la investigación desarrollada en la identificación de primitivos semánticos dentro de la categoría Actions, events, movement, contact estableciendo el exponente en inglés antiguo para el primitivo DO. Con este fin, este artículo evalúa la aptitud de distintos verbos en inglés antiguo como posibles exponentes del primitivo en cuestión mediante un análisis basado en la frecuencia textual, morfología, semántica y complementación sintáctica del verbo en cuestión. La información para el análisis ha sido extraída, principalmente, de la base de datos del inglés antiguo Nertbus, del Dictionary of Old English (Healey et al. 2018) y del Dictionary of Old English Corpus (Healey et al. 2009).

Palabras clave: Natural Semantic Metalanguage, primitivos semánticos, lingüística histórica, inglés antiguo, valency options.

Received 20 December 2019

Revised version accepted 3 March 2020

\section{INTRODUCTION}

The Natural Semantic Metalanguage (henceforth NSM) theory is based on the assertion that there is a set of core concepts that can be found cross-linguistically. These concepts are called semantic primes and they are described as simple, indefinable terms. The main assumption of the NSM model is that by means of the principle of reductive paraphrase and by applying the appropriate grammatical rules, these primes are able to describe complex concepts in terms of simple ones in every natural language.

These concepts have the property of being universal, this is, they can be found cross-linguistically and they are able to express any meaning in a natural language. It is precisely this universality what has led many researchers to identify these concepts in several living languages. However, to test this universal property, some researches have emerged on the identification of primes in historical languages such as Old English (hereafter OE).

The latest studies within this line of research have been conducted in the category Actions, events, movement, contact from which the OE exponents TOUCH, HAPPEN and MOVE have been identified (Mateo Mendaza 2013, 2016a, 
2016b). ${ }^{2}$ In order to complete the work conducted on this category, this research intends to select the OE exponent for the semantic prime DO and, by focusing on the conclusions derived from each analysis, to establish a proper methodology to study semantic primes in historical languages.

This article is organised as follows: in section 2, an explanation of the main hypothesis of the NSM model is provided along with a description on the work made on semantic primes in OE to date. Section 3 describes DO from the NSM perspective and lists the possible candidates for prime exponent in OE. At this point, the relationship between the Present-Day English exponent of DO and the candidate (ge)dōn emerges. The following section proposes a methodology based on an array of criteria for exponent selection, which is later applied to the verb candidates (Section 4 and Section 5). Section 6 discusses prime selection and secondary meanings related to the dichotomy do/make; finally, the main conclusions drawn from this research are presented in Section 7.

\title{
2. SEMANTIC PRIMES
}

After the first proposal on semantic primes presented by Anna Wierzbicka in the early seventies, along with the work by Cliff Goddard, the NSM theory has been refined and expanded to reach its current status as one of the most important theories within the field of lexical semantics. This semantic theory is based on the assumption that:

\begin{abstract}
Semantics can have an explanatory value only if it manages to "define" (or explicate) complex and obscure meanings in terms of simple and self-explanatory ones. If a human being can understand any utterances at all [...] it is only because these utterances are built, so to speak, out of simple elements which can be understood by themselves. (Wierzbicka 1996: 12).
\end{abstract}

These simple elements are referred to as semantic primes and they share the property of being also universal, that is, they can be found in all languages.

The inventory of primes, which was first published in 1970, was comprised of fourteen semantic primes. This initial inventory has been updated by adding and rearranging semantic primes to adapt them to current thinking. Nowadays, the list of semantic primes consists of sixty-five primes divided into seventeen different categories. Figure 1 displays the inventory of primes in English and, some of them, are presented along with their allolexes or allomorphs, which represent the language dependent variant forms that the prime may adopt depending on the context (indicated by $\sim$ ).

2 The NSM research team has recently updated the inventory of primes and some of them have been rearranged. This affects the category under analysis, which is currently called Actions, events, movement. Therefore, it leaves out the prime TOUCH, which is now included within the category Possession. Nevertheless, the results obtained from this analysis will also be compared with TOUCH in the review. 


\begin{tabular}{|c|c|}
\hline I, YOU, SOMEONE, SOMETHING THING, PEOPLE, BODY & substantives \\
\hline KIND, PART & $\begin{array}{r}\text { relational } \\
\text { substantives }\end{array}$ \\
\hline THIS, THE SAME, OTHER ELSE & determiners \\
\hline ONE, TWO, SOME, ALL, MUCH MANY, LITTLE FEW & quantifiers \\
\hline GOOD, BAD & evaluators \\
\hline BIG, SMALL & descriptors \\
\hline KNOW, THINK, WANT, DON'T WANT, FEEL, SEE, HEAR & mental predicates \\
\hline SAY, WORDS, TRUE & speech \\
\hline DO, HAPPEN, MOVE & $\begin{array}{r}\text { actions, events, } \\
\text { movement }\end{array}$ \\
\hline BE (SOMEWHERE), THERE IS, BE (SOMEONE/SOMETHING) & $\begin{array}{r}\text { location, existence, } \\
\text { specification }\end{array}$ \\
\hline (IS) MINE & possession \\
\hline LIVE, DIE & life and death \\
\hline $\begin{array}{l}\text { WHEN TIME, NOW, BEFORE, AFTER, A LONG TIME, A SHORT } \\
\text { TIME, FOR SOME TIME, MOMENT }\end{array}$ & time \\
\hline $\begin{array}{l}\text { WHERE PLACE SOMEWHERE, HERE, ABOVE, BELOW, FAR, } \\
\text { NEAR, ON ONE SIDE, INSIDE, TOUCH }\end{array}$ & place \\
\hline NOT DON'T, MAYBE, CAN, BECAUSE, IF & logical concepts \\
\hline VERY, MORE ANYMORE & $\begin{array}{r}\text { augmentor, } \\
\text { intensifier }\end{array}$ \\
\hline LIKE $\sim$ AS WAY & similarity \\
\hline
\end{tabular}

Figure 1. Semantic primes: English exponents and allolexes (NSM webpage).

As explained by Wierzbicka in the quotation above, the NSM theory relies on the principle of reductive paraphrase, which stipulates that complex meanings can be expressed in terms of simple ones. Thus, semantic primes combine with one another to define the meanings of complex concepts in a such a way that they avoid unnecessary abstraction, circularity and the use of obscure definitions. The resulting product obtained from the combination of primes is called explication. Explications make use of semantic primes and, in cases in which meanings are much more complex, of semantic molecules. Semantic molecules are defined by Goddard (2011: 71) as: "non-primitive meanings that function, alongside the semantic primes, as conceptual building blocks in the meaning structure of other, yet more complex words". Semantic 
molecules include terms such as hand, long, round, etc. They are marked by the notation $[\mathrm{m}]$. Figure 2 sets an example of how explications work within the NSM model and how semantic molecules can be inserted within these descriptions.

\section{bead (someone's head)}

a. one part of someone's body

b. this part is above all the other parts of the body

c. this part is like something round [m]

d. when a person thinks about something, something happens in this part of this someone's body

Figure 2. Explication for the word head (Goddard 2012: 7).

Although the NSM relies on semantic grounds to manifest the universality of primes, it should be remarked that primes have an inherent grammar, which has also the quality of being universal. This means that the combinatorial properties of primes are found cross-linguistically, although its formal realisation may vary from one language to another. In this sense, each prime has a canonical syntactic frame -minimal frame- in which a predicate such as HAPPEN can be found along with a substantive phrase, such as SOMETHING. However, the nature of a predicate may allow for extended syntactic configurations in which this prime may occur. These optional syntactic frames are called valency options within the NSM theory and each option is labelled under the traditional set of semantic roles. An example of the valency options proposed for HAPPEN and its semantic roles is displayed in Figure 3.

\begin{tabular}{|ll|}
\hline something HAPPENS & [minimal frame] \\
something HAPPENS to someone/something & [undergoer frame] \\
something HAPPENS somewhere & [locus frame] \\
\hline
\end{tabular}

Figure 3. Minimal frame and valency options for HAPPEN (Goddard 2015: 3).

This said, many researchers, led by Wierzbicka and Goddard, have contributed to the improvement and enlargement of the NSM theory, thus giving rise to the Natural Semantic Metalanguage Research Programme (NSMRP). This program involves research on different disciplines such as 
language acquisition, ethnography and non-verbal communication, although the most productive research has been conducted in the identification of these primes in several languages. Semantic primes exponents have been researched in more than 70 languages, including Russian, French, Arabic, Malay, Amharic (Ethiopia), Korean, East Cree (Canada) or Yankunytjatjara (Australia), among others.

Against this background and given that the identification of primes has been made on living languages, a new line of research that focuses on the identification of primes within historical languages has been pursued in the last years. The language selected for these studies was OE and research on this language has been conducted, initially, by Martín Arista and Martín de la Rosa (2006), who deal with the OE exponents for the primes included within the categories Substantives, Determiners and Quantifiers. After that, de la Cruz Cabanillas (2007) and Guarddón Anelo (2009) continued this work by establishing the OE exponents for the descriptors BIG and SMALL and of some adpositions, respectively. Their studies are grounded on the assumption that there is no direct way to check the adequacy of prime exponents due to the lack of native speakers of this language. This situation entails to select prime exponents by means of indirect methods based mainly on corpus work. These authors propose text-frequency as the central criteria in their analysis, although the syntax of the candidates is also taken into consideration by some of them (Martín Arista and Martín de la Rosa 2006; de la Cruz Cabanillas 2007). From these studies the idea of expanding on this line of research emerged. Recent research on OE semantic primes has focused on the primes TOUCH (Mateo Mendaza 2013), HAPPEN (Mateo Mendaza 2016a) and MOVE (Mateo Mendaza 2016b), included within the previously called category Actions, events, movement, contact. These studies elaborate on the idea that exponent identification in historical languages should rely on an array of textual, morphological, semantic and syntactic criteria that determine the suitability of a word as prime exponent. At the same time, by refining the methodology in the course of each study, this research line aims at establishing a principled methodology that motivates the identification of prime exponents in other historical languages.

\section{THE SEMANTIC PRIME DO: SELECTION OF CANDIDATES FOR PRIME EXPONENT}

From the NSM perspective, DO is described as a semantic prime associated with the concept of "action" and, as such, it belongs to the category Actions, events, movement, contact. 
SEMANTIC PRIMES IN HISTORICAL LANGUAGES. THE IDENTIFICATION OF THE OLD ENGLISH..

Within this framework, the meaning of DO is closely related to that of "perform, accomplish, effect". It is described as a transitive verb with an obligatory agent slot and an action complement, and it is inherently related to a time adjunct. This canonical syntactic frame also allows for variation in manner, as "SOMEONE DOES SOMETHING LIKE THIS (=IN THIS WAY)" (Goddard 2008: 72). Apart from this minimal frame, valency options associated to patient, instrument and comitative slots are available in universal grammar for the primitive DO (Goddard and Wierzbicka 2002: 52).

Against this background, the search for the OE exponent for DO requires a revision of all the OE transitive verbs conveying the meaning "to do" in order to select all possible candidates for prime exponent. With this purpose, the The Historical Thesaurus of the Oxford English Dictionary (henceforth HTOED, Kay et al. 2009) has been consulted. This source provides a list of ten different candidates for prime exponent, viz., gegān, (ge)gearwian, (ge)lōstan, (ge)macian, (ge)dōn, (ge)pēon, wracian, (ge)drēogan, (ge)wyrcan and gedibtan. Apart from the information of the thesaurus, it is important to check the full meaning of these verbs in other OE lexicographical sources, such as Bosworth-Toller's (1973), Hall's (1996) and Sweet's (1976) dictionaries and the Dictionary of Old English: online A to I (Healey et al. 2018), to examine the centrality of "to do" within each candidate. After this search, some candidates are directly discarded from this research as they do not include "to do, perform" as their primary meaning. This is the case of (ge) dibtan, whose core meaning is "to put in order, dispose, arrange"; gegān which is defined as "to go"; (ge)gearwian, which means "to prepare, make ready"; and (ge)löstan, which gives preference to the meaning "to follow, attend". The same happens to wracian which is listed on the dictionaries with the meaning "to be banished, be in exile" and, indeed, is marked in the Thesaurus of Old English (Roberts et al. 2000) as a very infrequent word. In the case of (ge)wyrcan, it is a highly used verb in the OE language, but both its semantics and etymology directly relate this verb to the meaning "to work, labour" (Orel 2003: 457).

On the other hand, the verbs (ge)macian, (ge)dōn, (ge)pēon and (ge)drēogan are defined with the meaning "to do" as their core meaning and, thus, they can be proposed as potential candidates for prime exponent. Nevertheless, a first sight at the list of candidates reveals that, in formal grounds, the verb (ge)dōn stands out from the rest of verbs. It seems to be a strong relationship between the verb (ge) dōn and the Present-Day English (hereafter PDE) exponent of DO, that is, the verb do. Regarding their etymology, different authors including Skeat (1993: 121), point out that these words are closely related. This is also confirmed by Orel (2003: 73), who traces back to the Indo-European origins of the PDE meaning "to do, make" as follows: "dhe (IE) < 'ðōnan (ProGr) < dōn (OE). 
Indeed, many authors such as Visser (1984), Mitchell (1985) and Denison (1993) concur on the grammatical relationship between the verb (ge)don and the PDE verb do and, on this basis, they establish the evolution of $d o$ from the OE period to the present. During the OE period, the verb (ge)don $n$ was able to assume different functions in the language and most of them are also available nowadays. The attested uses for (ge)don were the full verb $d o$, proverb(al) $d o$ and causative $d o$. In its full form, the transitive use of (ge)dōn as "perform, accomplish" concurs with the main meaning of the PDE form. However, in some early texts (ge)dōn was also used transitively with the meaning "to put, place" (Denison 1993: 256), but this use is not attested anymore. Furthermore, although less frequently, (ge)dōn was also used as an intransitive verb meaning "to act" and "was usually cataphoric or anaphoric for another verb" (Denison 1993: 256). This intransitive use is still found in PDE in sentences such as "They are free to do as they please" (Oxford Learner's Dictionary 2020). The general term proverb(al) do corresponds to what other authors call substitute do or vicarious do (Denison 1993: 271). Proverb(al) constructions with the verb do are frequently found in PDE. Its origins go back to the OE period, when the verb (ge)dōn could be used in reference to a foregoing verb. As a proverb, (ge)dōn could copy the constructions of the verb which it stood for. This use is thought to have influenced the existence of the auxiliary use of $d o$ in the language (Denison 1993).

On the contrary, the causative use of (ge)dōn is not represented in PDE due to the evolution undergone by this construction. In OE causation was expressed by the verbs (ge)dōn, hatan, and latan (Ringe and Taylor 2014) although other verbs could also perform this function ${ }^{3}$. In the Middle English period, new verbs such as cause, get, have, and make developed this causative meaning. This fact contributed to the disappearance of the causative meaning of $d o$, which was attested during the $16^{\text {th }}$ century for the last time (Denison 1993: 257).

All these reasons determine the connection between the OE (ge)dōn and PDE $d o$ and strongly suggest that (ge)don could be seen as the OE exponent for the semantic prime DO. However, the search of prime exponents is a synchronic issue and, thus, it is necessary to study the different candidates proposed on their own to check their role within the OE language.

With this purpose, these candidates are going to be studied under an array of different criteria that will establish their suitability as prime exponent. However, due to prior arguments, the results of (ge)dōn will be taken as the benchmark for the comparative analysis carried out within each criterion.

3 See Royster (1922) for a thorough analysis of OE causatives. 
SEMANTIC PRIMES IN HISTORICAL LANGUAGES. THE IDENTIFICATION OF THE OLD ENGLISH...

\section{SELECTING CRITERIA FOR PRIME EXPONENT}

As in previous studies (Mateo Mendaza 2013, 2016a, 2016b), the methodology of this research consists of two steps. Firstly, potential candidates for prime exponent are selected on the basis of the information provided by lexicographical sources. Secondly, the prime exponent is identified by means of a set of morphological, textual, semantic and syntactic criteria. Some of these criteria have proved more conclusive than others for the identification of prime exponents in OE, specifically the semantic and syntactic ones (Mateo Mendaza 2016a). This is due to the fact that the results provided by morphological and textual criteria are prone to be affected by different linguistic phenomena, such as polysemy and homonymy; whereas the syntactic and semantic criteria would turn out more consistent results since they are the core of the NSM theory. Nevertheless, the four types of criteria must be taken into account in order to test the centrality of the word selected as prime exponent.

The requirements involved by the morphological and textual criteria are based on the notion of productivity posed by Bauer (2001). Bauer states that the productivity of a given process can be decomposed into availability and profitability (2001: 205). Availability entails that a process is accessible to create new words in a given period; whereas profitability is a quantitative concept that assesses the number of words created under the process at stake. In this sense, the morphological criterion stipulates that the prime exponent is a core word within the language available for the speaker to create a significant number of new words, thus being profitable. Therefore, this exponent is expected to be the base of derivation for several words or even the primitive of a large lexical paradigm in which words of different categories are created by means of different word formation processes.

Regarding the textual criterion, the exponent selected is expected to be frequent within the language since this would imply that this word is maximally available for the speaker of that language. For this reason, the number of textual types found for the verb under analysis, that is, the different inflected forms and realizations of the verb at stake, and tokens, the occurrences of each type within the corpus, are taken into account when gauging the textual criterion $^{4}$.

Finally, semantic and syntactic criteria stipulate that the exponent resembles the requirements of the semantic prime as much as possible. In this respect,

\footnotetext{
4 The term "textual type" as used in this article makes reference to the unlemmatized forms of the verb found within the corpus; as opposed to the term "type" which refers to the lemmatised form found as the entry of a dictionary.
} 
although polysemy may affect the candidate, the word selected should have a core meaning similar to that of the semantic prime. Regarding syntax, as explained in section 2, semantic primes present a basic syntactic configuration -minimal frame-, but there are also other possible syntactic frames -valency options- associated with each prime (Goddard 2015). Therefore, the word selected as prime exponent must conform to the prototypical minimal frame, but also to the valency options of the prime under analysis.

The identification of the semantic prime exponent in terms of the criteria mentioned above, calls for the use of different lexicographical and textual sources to gather relevant data of the candidate words. In order to check the category, status and inheritance relations of the verb selected, the lexical database of OE Nerthus (www.nerthusproject.com) has been consulted (accessed on the 21 $1^{\text {st }}$ February 2019). This database contains ca. 30,000 entries based on Hall's (1996) Bosworth-Toller's (1973) and Sweet's (1976) dictionaries. For each entry semantic information, as well as a description on the inflection and derivational paradigms of each word, is given. On the other hand, the type frequency of the exponent and the token frequency presented by each form, have been counted up by consulting the Dictionary of Old English Corpus (DOEC, Healey et al. 2009). Additionally, the Dictionary of Old English: online A to I (DOE, Healey et al. 2018) has been consulted in order to retrieve the semantic frames and syntactic behaviour of the verbs at stake. For those verbs not included in the DOE, Bosworth-Toller's (1973) dictionary has been used. Finally, in order to find instances of the selected candidate corresponding to the different frames of DO, the DOEC (Healey et al. 2009) has been accessed. The excerpts selected as relevant examples belong to some of the most important OE works, such as, The Old English History of the World: An Anglo-Saxon Rewriting of Orosius (Godden 2016), Bede's Ecclesiastical History of the English People. Part I 1 (Miller 1959a), Bede's Ecclesiastical History of the English People. Part I 2 (Miller 1959b) and The Homilies of the Anglo-Saxon Church (Thorpe 2011).

\section{ANALYSIS}

On the basis of previous studies on OE semantic primes (Mateo Mendaza 2013, 2016a, 2016b), the methodology applied to the selected verb for the OE exponent for the prime DO consists of an array of criteria in which the morphology, semantics, syntax and textual occurrences of (ge)don $n$ and the rest of candidates are revised.

The first step of analysis is to look at the morphology of the candidates. As previously commented, the morphological criterion requires that the word selected 
as prime exponent constitute a base of derivation of a productive paradigm. A search for the lexical paradigm of the verb (ge)don on Nerthus database launches 38 results. These results are displayed in the following lines, where the members of the paradigm are itemized in terms of their status and category and each word is presented along with their PDE translation:

\section{Primitive}

- Verb:

(ge)dōn (to do, make, act, perform; to put, place; to reach, achieve; to make, cause, effect; to take (from, to or away); to give, confer, bestow; to consider, esteem; to observe; to keep; to remove, put away; to put to death; to expend, apply (money); to shew mercy, do honour; to give, supply, furnish)

\section{Prefixation}

- Verb:

$\bar{A} d \bar{n} n$ (to take, take away, remove; to send away, set free, cast out, expel, banish; to destroy; to put, place), aetdōn (to take away, deprive), bedōn (to shut); forðdōn (to put forth); fordōn 1 (to undo; to bring to nought, ruin, destroy, kill; to seduce, defile, corrupt); forgedōn (to undo, bring to naught, ruin, destroy, abolish, kill; to corrupt; to seduce, defile), framādōn (to do or take from or away; to cut off); fuldōn (to perform, complete, satisfy; to arrange); misdōn (to act wrongly, err, offend, transgress, do evil); oðdōn (to put out); ofādōn (to pull out, tear out), ofdōn (to put out, put off, take off (clothes)); oferdōn (to overdo, do to excess); onādōn (to put on); ondōn 2 (to put on (clothes)); tōdōn (to apply, put to, add; divide, separate, distinguish; undo, open, unbind); Jurhdōn (perficere); undōn (to undo, open, loosen, separate; cancel, discharge, abrogate, destroy); ungedōn (not done); ymbdōn (to put round, encompass)

- Adjective

fordōn 2 (corrupt, wicked; abandoned); onfordōn (destroyed)

\section{Suffixation}

- Noun:

Dōere (doer, worker); ondōung (injection)

- Adjective:

Dōnlic (active); undōnness (state of being undone) 


\section{Compounding}

- Verb:

Ingedōn (to put in); underdōn (to put under); weldōn (to do well; benefit, satisfy, please);

- Noun:

Almesdōnd (almsgiver); gōddōnd (Benefactor); Unribtdōn (evildoer); Yfeldōnd (evildoer)

- Adjective:

Ārgedōn (done before); Rihtdōnde (doing what is right); Welgedōn (welldone, good, beneficent)

\section{Zero derivation}

- Adjective:

fordōn 2 (corrupt, wicked; abandoned)

Regarding the status of (ge)dōn, this anomalous verb is the primitive of lexical derivation from this paradigm. Moreover, the derived words of the paradigm are created directly from the primitive. Therefore, all of them maintain part of the core meaning of the verb, as in the case of framadon "to do or take from or away; to cut off" or dōnlic "active" among others. Besides, these words are created by means of the most significant word formation processes, this is, prefixation, suffixation, compounding and zero derivation and they belong to major lexical categories (nouns, verbs and adjectives).

As for the rest of candidates, whereas (ge)pēon is a derivationally unrelated verb without derivatives on its own, (ge)drēogan and (ge)macian are also the primitive word of their lexical paradigms. In this sense, as displayed by Nerthus database, (ge)macian only creates one prefixed verb and one suffixed noun, so its paradigm cannot be seen as a productive one. On the contrary, (ge)dréogan presents 13 derivatives that belong to all major lexical categories and are formed by means of suffixation, derivation and zero derivation.

Despite the results of (ge)drēogan satisfy the requirements of the morphological criterion, the data displayed by (ge)don exceeds by far these results with 38 derivatives of its own and, thus, it is considered a more suitable candidate for prime exponent.

Moving to the textual criterion, which examines the frequency of the verbs under analysis within the OE period, the DOEC (Healey et al. 2009) presents the results conveyed in Table 1. 
SEMANTIC PRIMES IN HISTORICAL LANGUAGES. THE IDENTIFICATION OF THE OLD ENGLISH...

Table 1. Textual occurrences for the candidate verbs in the DOEC (Healey et al. 2009).

\begin{tabular}{|c|c|c|c|}
\hline Type & Occurrences & $\begin{array}{c}\text { Textual } \\
\text { types }\end{array}$ & $\begin{array}{l}\text { Textual } \\
\text { tokens }\end{array}$ \\
\hline$(g e) d \bar{n} n$ & $\begin{array}{l}\text { do (2094), dyde (1629), don (1318), gedon (830), dom } \\
\text { (759), deað (647), deð (635), dydon (573), donne (275), } \\
\text { gedo (268), doede (244), dydest (220), gedyde (218), } \\
\text { dep (201), dest (171), dem (139), donde (133), gedeð } \\
\text { (117), dide (115), doeð (83), gedydon (81), doa (67), } \\
\text { gedone (58), det (5), doe (50), des (46), didon (45), } \\
\text { dydan (43), gedep (40), dondum (38), doo (37), gedoð } \\
\text { (37), dydes (34), dede (32), dydun (30), dyden (29), } \\
\text { doende (26), doem (25), doas (25), done (24), does (23), } \\
\text { gedydest (22), gedest (21), gedoe (21), didest (20), diden } \\
\text { (17), дo (17), gedoeð (17), gedoeð (17), dydyst (16), } \\
\text { doest (15), gidoe (14), dedon (13), doam (12), doon } \\
\text { (12), dondes (11), doep (10), doeð (10), gedonne (10), } \\
\text { gedoa (10), doep (9), gidyde (8), gedydan (8), doan (7), } \\
\text { doanne (7), doen (7), dondan (7), doynde (7), doend } \\
\text { (7), gedoo (7), gedoen (6), gidoa (6), gedop (6), deden } \\
\text { (5), gedide (5), gedoon (5), dedun (4), doendo (4), } \\
\text { gedom (4), gedoað (4), duden (3), dedan (3), doom (3), } \\
\text { dcedon (3), dydo (3), gedoan (3), gedidest (3), gidoas } \\
\text { (3), gidoeð (3), gedoest (3), destu (2), doces (2), doenne } \\
\text { (2), doyndum (2), doendum (2), doynne (2), deð (2), } \\
\text { doedun (2), deodan (2), dudest (2), didan (2), dydestu } \\
\text { (2), gedyden (2), gedoap (2), gedem (2), gedede (2), dyst } \\
\text { (1), dep (1), dyð (1), dot (1), dood (1), dydoe (1), dydede } \\
\text { (1), dyd (1), dydost (1), dides (1), dedest (1), dedyst } \\
\text { (1), dudon (1), deodon (1), deoden (1), dydyn (1), } \\
\text { doane (1), doonde (1), dode (1), dondne (1), doyndys } \\
\text { (1), doyndan (1), dodum (1), donden (1), donan (1), } \\
\text { gedoom (1), gedoest (1), gedet (1), gidoes (1), gedoces } \\
\text { (1), gedoas (1), gido (1), gedeo (1), gaedo (1), gedydyst } \\
\text { (1), gedydost (1), gedidon (1), gededan (1) }\end{array}$ & 144 & 12,023 \\
\hline (ge)drēogan & $\begin{array}{c}\text { dreogan (34), drugon (23), dreogað (18), dreah } \\
\text { (16), dreogende (14), dreogeð (12), dreoge (10), } \\
\text { dreag (8), drybð (5), drogan (4), dribð (3), dreogest } \\
\text { (3), druge (3), drugan (3), dreob (2), drigen (2), } \\
\text { drigð (2), gedreogeð (1), gedribð (1), gedrigð (1), } \\
\text { gedreab (1), droge (1), drigast (1), dribst (1), drigip } \\
(1), \text { dreogap (1), dreagceð (1), drub (1), drohgende } \\
(1), \text { dreogendes (1), dreoganne (1), dreogenne (1), } \\
\text { dreigen (1), dricen (1) }\end{array}$ & 34 & 179 \\
\hline
\end{tabular}




\begin{tabular}{|c|c|c|c|}
\hline Type & Occurrences & $\begin{array}{c}\text { Textual } \\
\text { types }\end{array}$ & $\begin{array}{l}\text { Textual } \\
\text { tokens }\end{array}$ \\
\hline (ge)pēon & 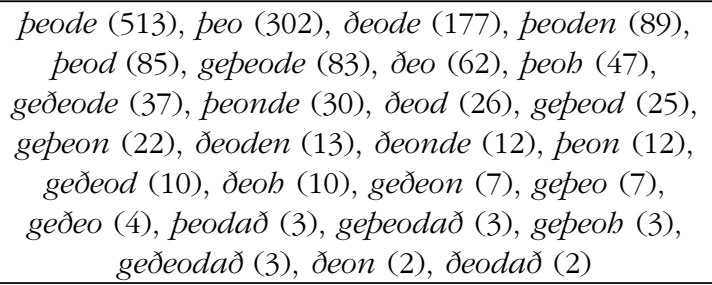 & 27 & 1,589 \\
\hline (ge)macian & $\begin{array}{l}\text { maciað (48), macian (28), macode (18), gemacod } \\
\text { (10), macodon (6), maca (5), gemaciað (2), } \\
\text { macast (2), macap (2), macie (2), gemacie (1), } \\
\text { gemacedon (1), gemacion (1), macicen (1), } \\
\text { maciende (1), maciende (1), macion (1) }\end{array}$ & 17 & 130 \\
\hline
\end{tabular}

The textual criterion asks for a maximally available word as prime exponent, so, a high number of both textual types and tokens within the OE corpus will determine the candidate that was regularly accessible for the speakers during the OE period.

In this respect, the results select the verb (ge)don as prime exponent, as it clearly outnumbers the rest of candidates in terms of frequency, with 144 types and 12,023 tokens. Indeed, the figures displayed by (ge)dōn also surpass the ones presented by other verbs selected as prime exponent for the semantic primes included within the same category as DO identified in previous research. This is the case of the verb (ge)hrinan, exponent of TOUCH, which presented 31 types and 216 textual tokens; (ge)limpan, exponent of HAPPEN, with 30 types and 584 tokens; and (ge)styrian, exponent of MOVE, showing 52 types and 272 occurrences within the OE Corpus (Mateo Mendaza 2013: 460; 2016a: 584; 2016b: 551). The high frequency of (ge)dōn is determined by different reasons. Regarding its inflectional morphology, there is agreement on the statement that, despite the group of anomalous verbs, such as (ge)donn, is quite small, their frequency is exceptionally high (Diamond 1970: 33; Quirk and Wrenn 1994: 53; Hogg and Fulk 2011: 308). On the other hand, it is important to highlight that, as discussed in previous research (Mateo Mendaza 2016a), the textual criterion is the less conclusive one given that the results derived from the counting of tokens can be altered in different ways. Within this criterion, results are affected by homonymy, as some types of (ge)don share the same form to other words in $\mathrm{OE}$ that do not belong to the same paradigm. This is the case, for example, of the form dom, an attested form for the present indicative of (ge)donn, that can be misled with the noun $d \bar{o} m$ "judgment, sentence, doom, ordeal", given that 
the corpus does not show the length of the vowels. Besides, as discussed in section 3, apart from the core meaning "to do, perform", (ge)dōn is polysemic in its transitive form and there are other uses attributed to this verb, such as the intransitive, proverbal and causative ones. These uses might also influence the number of tokens.

Similarly, the second candidate in terms of frequency, this is, the verb (ge) peeon with 27 types and 1,589 tokens, is also affected by homonymy. Within the OE language there are three different verbs that share the form (ge)pēon in their infinitival form. Dictionaries show an entry for (ge)pēon meaning "to tame, oppress", another one for (ge)pēon defined as "to grow, increase" and a third entry for the verb under investigation. The occurrences of these verbs would undoubtedly overlap each other. Furthermore, homonymy also takes place between (ge)pēon

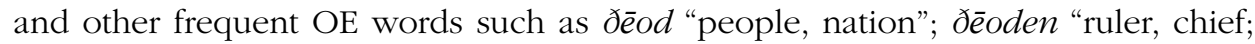
lord, prince, king" or (ge)ðēodan "to join, associate with", among others.

The other verbs, (ge)drēogan and (ge)macian, show low figures in the corpus and, thus, they cannot be considered proper candidates. In fact, even the results for these candidates are altered by polysemy, as many other meanings are attributed to these verbs in dictionaries.

Despite the setbacks affecting this criterion, the significant high frequency of (ge)don within the corpus suggests that, undoubtedly, it is considered a suitable candidate for prime exponent.

According to previous studies, the semantic and syntactic criteria will be studied at the same time. Coming back to the description of DO in terms of the NSM theory made in section 3, this prime refers to a transitive verb used to talk about actions in general. The meaning DO is closely related to that of "perform", "accomplish" or "effect".

In these terms, all verbs selected as candidates convey the meaning "to do, perform" as their primary meaning. However, at this point, it is necessary to describe the semantics of these verbs in detail. In the case of (ge)dréogan, the definitions for this verb found in different dictionaries suggest that (ge)drēogan contains certain nuances that imply a figurative meaning related to spiritual life. For example, Sweet's (1976) dictionary describes it as "to do (with effort)"; Hall's (1996) as "to lead a certain life, do, work"; Bosworth-Toller's (1973) reads "to do, work, perform, to pass life, to fight" for the simplex form and "to perform, finish, bear, suffer" for the complex one. This assertion is reinforced by the DOE, which states that the 175 occurrences of dréogan found in the corpus belong primarily to poetry (the complex form only displays 4 occurrences, as shown in Table 1). This poetical use implies that this verb is used in a metaphoric way. 
In the case of (ge)peon, it is important to highlight that this verb is not included in Sweet's (1976) dictionary for the meaning under investigation, whereas it provides entries for the two other homonymous verbs. In Hall's (1996) dictionary, the entry for (ge)pēon with the meaning "to perform, do" is marked as occurring exclusively in poetical texts. Similarly, although Bosworth-Toller's (1973) dictionary provides an entry both for its complex and its simplex form, there is only one example of each one to justify the existence of this meaning in the OE language. Within these examples, the simplex form is found in a poem, as suggested by Hall (1996), whereas the example for gepēon belongs to the Holy Gospels.

Moving on to (ge)macian, it is usually found in dictionaries with the meaning "to make, do, act; to make, cause" (Bosworth-Toller 1973); "to arrange, manage" (Sweet 1976), "to make, form, construct, do" (Hall 1996). The entries of the dictionaries imply that for (ge)macian there is a certain intention to do something and the focus is placed on the result, instead of in the action itself. This description of (ge)macian suggest that its meaning is far from the semantic prime, since it is more restricted than that displayed by other candidates. At this point, the semantic differences between do and make arises. This issue, affecting the identification of prime exponents in several languages, is thoroughly examined in the following section.

All in all, the semantics of (ge)pēon, (ge)drēogan and (ge)macian does not conform to the prototype and, thus, it does not make them good candidates for prime exponent and, consequently, their syntax is not examined in this research.

Concerning the semantics of (ge)dōn, all dictionaries consulted concur on the primary meaning "to do, perform, make" as its primary meaning. The DOE (Healey et al. 2018) provides detailed information on the semantic frames of (ge) $d \bar{o} n$, which are displayed in Figure 5. The frames in the DOE (Healey et al. 2018) match with those described by Denison (1993) in section 3. Hence, we can find the prototypical transitive use of (ge)don, other secondary meanings of this form, the intransitive, the causative, and its use as a pro-verb; although, as previously explained, only the former is considered in this research.

As this candidate does satisfy the requirements proposed by the semantic criteria, the next step of analysis calls for the study of the syntactic complementation of (ge)donn. Along with the information on the semantic frames of (ge)dōn, Figure 5 also displays the syntactic patterns found for (ge)dōn when adopting the primary meaning "to do". 
SEMANTIC PRIMES IN HISTORICAL LANGUAGES. THE IDENTIFICATION OF THE OLD ENGLISH...

\begin{tabular}{|c|c|c|}
\hline Predicate & Semantic Frames & Syntactic complementation (to do) \\
\hline$d \bar{n} n$ & $\begin{array}{l}\text { 1. to do, perform, act, achieve, } \\
\text { make } \\
\text { 2. to place, set, put (with } \\
\text { preposition or adverb of place) } \\
\text { II. as pro-verb (used to avoid } \\
\text { repetition) } \\
\text { III. causative (make, cause) }\end{array}$ & $\begin{array}{l}\text { 1.a in various phrases (to do service } \\
\text { (to), to do bateful evils, to inflict } \\
\text { pain,...) with noun complements } \\
\text { 1.b with adjective complement } \\
\text { 1.c with adverb or adverbial phrase } \\
\text { 1.d in various adverbial phrases } \\
\text { 1.e with adverbial clause of manner }\end{array}$ \\
\hline gedōn & $\begin{array}{c}\text { 1. to do, perform, act, achieve, } \\
\text { make } \\
\text { 2. causative } \\
\text { 3. to place, set, put } \\
\text { 4. to give } \\
\text { 5. to arrive, to encamp } \\
\text { 6. pro-verb (to avoid repetition) }\end{array}$ & $\begin{array}{c}\text { 1.a. with noun complement (in various } \\
\text { phrases) } \\
\text { 1.b. with adjectival complement (in } \\
\text { various phrases) } \\
\text { 1.c. with adverb } \\
\text { 1.d. with various adverbial phrases } \\
\text { 1.e. with adverbial clause of manner }\end{array}$ \\
\hline
\end{tabular}

Figure 5. Semantic frames and syntactic behaviour of the verb (ge)don as found in the DOE (Healey et al. 2018).

In terms of syntax, the NSM theory defines the primitive DO as an action predicate (realised as a direct object) that opens an obligatory agent slot (subject) and an obligatory action complement slot. Regarding this complement, Goddard (2008) points out that only a subset of primes can occur with a substantive complement, as it is the case of DO. Besides, the prime DO requires an (obligatory) time slot, and an optional place slot (Wierzbicka 1996; Goddard 1997). Recent studies have detected that DO and other predicate primes also allow for variation in manner (Goddard 2008). As it is shown in Figure 5, (ge)donn satisfies the syntactic requirements of the primitive, given that, with the meaning "to do", both the simplex and complex forms of the verb are primarily followed by a substantive complement in order to fulfil its meaning. Apart from the more canonical substantive complement, the OE exponent (ge)dōn is also able to appear with adjectival complements or adverbial phrases and clauses acting as complements. Indeed, in both cases, adverbial clauses are specified to be "of manner". In this way, the manner property associated to the prime DO is satisfied as exemplified in 1a. Moreover, the examples provided by the DOEC (Healey et al. 2009) show that the optional locative is also found in some sentences with (ge)dōn, as in $1 \mathrm{~b}$; and the obligatory temporal reference is always present in an implicit (1a) or explicit manner (1b-c).

(1a.)

[Bede $2025100(9.132 .1)]$ 
Dyde se cyning swa hit ær cweden wæs; nales pæt an pæt he ðone wreccan to cwale ne gesealde, ac eac swylce him gefultumade, pæet he to rice becwom.

The king did as it has been said; he not only did not give up the exile to death, but also aided him in attaining to the throne. (Miller 1959a: 132)

(1b.)

[Or $4025400(8.100 .27)]$

Æfter pæm Scipia se consul, pæs opres Scipian bropor, wæs monega gefeoht donde on Ispanium, \& Magonem Pena latteow gefeng.

After that the consul Scipio, brother of the other Scipio, fought many battles in Spain and captured the Carthaginian general Mago (Godden 2016: 267)

(1c.)

[Bede 2030100 (11.140.11)]

\& he noht elles dyde eallum pam dagum from ær morgenne oð æfen, pon pæt cumende Cristes folc pider of eallum tunum \& stowum mid godcundre lare timbrede <ond> synna forlætnesse bæðe aðwog in pæm streame pe <Glene> is nemned.

And every day from early morning till evening he did nothing but instruct Christs people in the word of God, who flocked there from all villages and places, washing them in the 1aver of the remission of sins at the river called the Glen (Miller 1959a: 141)

As explained at the beginning of this article, there are universal correspondences between the lexical meanings of primes and also between the ways these primes can combine to each other. These universal combinations are termed valency options. In this case, apart from the prototypical syntactic frame - minimal frameof the semantic prime DO, this predicative prime accepts other valency options (optional arguments) related to patient, instrument, body-part or comitative slots:

\begin{tabular}{|ll|}
\hline a. someone DOES something & [minimal frame] \\
b. someone DOES something to someone else & [patient1 frame] \\
c. someone DOES something to something & [patient2 frame] \\
d. someone DOES something with something & [instrument frame] \\
e. someone DOES something with part of the body & [body-part frame] \\
f. someone DOES something with someone & [comitative frame] \\
\hline
\end{tabular}

Figure 6. Valency options of DO (Goddard 2015: 3). 
As a universal aspect, these valency options can be also found in the OE language with the verb (ge)dōn, as demonstrated in the examples in (2a-f), retrieved from the DOEC (Healey et al. 2009).

(2a) Minimal frame

[Bede 2009900 (4.108.5)]

Ac peah pe he pas ping dyde, hu swiðe him speow, nu gen pas ondweardan tide, pa ilcan peowas cyðað.

And though he did so, the present times and the same usages prove, how little be succeeded. (Miller 1959a: 109)

(2b) Patient frame1

[Or $6027500(34.152 .28)]$

On pæm ðriddan geare his rices, pa he pæt mæste woh dyde wið pa Godes peowas, pa adrifon hine Gotan ut of hiora earde, \& hie foran sippan ofer Donua pa ea on Ualenses rice, \& wilnedon to him pæt hie mosten on his rice mid friðe gesittan.

In the third year of his reign, when he was doing great injury to the servants of God, the Goths drove him out of their territory and then advanced over the river Danube into Valens, territory; and asked him to give permission for them to settle in his empire under protection (Godden 2016: 405)

(2c) Patient frame2

[ÆCHom I, 26006100 (392.115)]

Simon ða mid deofles cræfte dyde pæt ðæs deadan líc styrigende wæs.

Simon then, through the devils craft, made the corpse of the dead to move. (Thorpe 2011: 372)

(2d) Instrument frame

[Or $3033100(11.80 .7)$ ]

\& heo gedyde mid hiere lare pæt ealle Mæcedonie wæron pæm cyninge wiðerwearde, op hie fundon pæt hie sendon æfter Olimpeadum, Alexandres meder, pætte hio him gefylste pæt hie mehton ægðer ge pone cyning ge pa cuene him to gewildum gedon.

Through her advice she caused all the Macedonians to be opposed to the king, to the point that they devised a plan to send for Olympias, Alexanders mother, to help them so that they could overpower both the king and the queen. (Godden 2016: 212) 
(2e) Body-part frame

[Bede $4025700(14.294 .23)]$

Mid py he ða hefgad wæs mid pa foresprecenan untrymnesse, \& he onget pæt him deaðes dæg toweard wæs, pa ongon pæs cynelecan modes monn him ondrædan, ponne he to deaðe cumende wære \& mid micle sare wæced py læs he owiht unwyrpes oðpe ungerisnes dyde mid his mupe, oðpe mid oðerra lima styrenesse.

Now when he was overpowered with the aforesaid infirmity, and felt that his death's day was at hand, then, being a man of royal character, be began to fear, lest on the approach of death, enfeebled by great pain, he might do something undignified or unbecoming, through the words of his mouth or the movements of his other members. (Miller 1959b: 294)

(2f) Comitative frame

[Bede $4049100(24.332 .20)]$

Pa onfeng heo anes heowscipes stowe to norðdæle Wiire pære ea, \& pær efenlice an ger munuclif dyde mid feawum hire geferum.

Then she received, to the north of the river Wear, ground sufficient for one family, and there similarly she lived one year, under conventual discipline with a few associate. (Miller 1959b: 332)

In fact, apart from these examples that demonstrate the adequacy of (ge)donn to the valency options of DO, the NSM proposed another syntactic configuration for this semantic prime, as it can be found in the 2017 updated version of its webpage (https://intranet.secure.griffith.edu.au/schools-departments/naturalsemantic-metalanguage: accessed on the $25^{\text {th }}$ January 2019). This valency option refers to "someone does something good (for someone else)/bad (to someone else), and one example for each meaning is displayed in (3a-b):

(3a) Do something good

[Bede $5035200(14.440 .27)]$

pæt he cwæð, pæt hie ærest ða fægran boc \& ða hwitan englas forðbrohton, \& æfter pon deofol pa sweartan, \& hi pa englas swiðe medmicle ond pas unmætan, pæet is to ongeotene, pæt he in ðære ærestan ældo his lifes hwelchwugu god dede, ða he hwæðre in midfeorum life ealle ðurh his unrihte dæde aðeostrade \& fordilegade.

Whereas he said that the angels brought forth first the fair and white book, and after that devils the black book, and the angels a very small and the others a monstrous one, by this we are to understand that he did some good in the first years of his life, which in middle age he obscured and blotted out completely by his unrighteous deeds. (Miller 1959b: 440) 
SEMANTIC PRIMES IN HISTORICAL LANGUAGES. THE IDENTIFICATION OF THE OLD ENGLISH...

(3b) Do something bad

[Or $6026800(34.152 .11)]$

He pa Ualens oðewde openlice pæt he ær diegellice gehyd hæfde, swa pæt he bebead pæt munecas, pe woroldlica ping forgan sculon \& wæpna gefeoht, pæt hie wæpena namen, \& mid pæm fuhte, \& yfel dyde mid oprum monnum.

Valens then revealed openly what he had previously bidden and ordered the monks, who were meant to abstain from worldly things and fighting with weapons, to take up arms and fight with them and do harm to other people. (Godden 2016: 402)

All this said, it can be concluded that both in terms of semantics and syntax, the verb (ge)don makes good candidate for the OE exponent of the semantic prime DO. This verb satisfies the requirement proposed by the prime DO, given that it expresses the core meaning of the primitive both in its simplex and complex form and, at the same time, the syntax of (ge)donn resembles that of DO both in complementation and valency options.

\section{DISCUSSION: THE DISTINCTION BETWEEN DO AND MAKE WITHIN THE NSM THEORY}

This study has revolved around the semantic prime DO, which is portrayed by the PDE verb do and, as demonstrated by the current analysis, the OE verb (ge) dōn. As previously commented, the prime DO refers to actions in general and it is used as a simple form to describe complex meanings similar to those implied by the verbs "perform", "accomplish" or "effect". However, within the description of this prime, the question on the differences between the English verbs do and make may emerge.

In terms of the NSM perspective, Goddard (2011) and Goddard and Wierzbicka (2002) have already pointed out that some semantic primes can have a secondary meaning in certain languages. There is attestation of polysemy involving the prime DO and make for some languages such as Malay, Arrernte, Samoan or Kalam (Goddard and Wierzbicka 2002: 25; Goddard 2008: 5) and this polysemy is also found for the OE verb (ge)donn as shown in the meanings provided by the DOE in Figure 5 displayed in the previous section. As the meaning of make is quite close to that of DO, the NSM theory considers make a semantic molecule included within the category of verbs of creation along with other verbs such as build or carve. Therefore, the meaning of make presents some nuances that Goddard and Wierzbicka explain in their research on the English lexicon of doing and happening: 
[M]aking something involves doing something for some time, and, moreover, doing it with physical things. Likewise, making something requires a degree of forethought and intention: having a clear outcome in mind (2016: 14).

Hence, the semantic difference between do and make is clear, being do a general -simple- term and make a more elaborated concept in which other nuances such as place and time references and a deliberate purpose take place.

Indeed, the reason for the manifestation of these dubious cases, as it is the distinction between $d o$ and make, is not merely semantic, but it is based on what Goddard (2011) describes as a tendency to anglocentrism found within this kind of studies. He talks about a natural predisposition to ethnocentrism, this is, describing the concepts of a given culture in terms a different cultural perspective, although no equivalents are found crossculturally (Goddard 2011: 14). Nowadays, becoming the English language a global way of communication, linguistic theories are revolving around anglocentrism. However, it should be pointed out that the NSM is a universal theory and the problems derived from the exponent selection on each study are language dependent. Therefore, the dichotomy do/make present in English does not affect all languages, so it should not be taken as a general question in exponent selection.

To clarify this question, some examples in Germanic and Romance languages are proposed. In the case of German, it presents the same distinction found in PDE, represented by the verbs "tun" (do) and "machen" (make), being the meaning of make closely related to that explained by Goddard in the citation above.

(4)

in einem Projekt etwas tun (do something in a project)

ein Armband machen (make a bracelet)

On the other hand, Romance languages do not make a difference in this context. The verbs "hacer", "faire" and "fare", express both the meaning of "do, perform" and "make, create" in Spanish, French and Italian, respectively, with a single word.

Hacer algo en un proyecto

Hacer una pulsera

Faire quelque chose dans un projet 
SEMANTIC PRIMES IN HISTORICAL LANGUAGES. THE IDENTIFICATION OF THE OLD ENGLISH...

Faire a bracelet

Fare qualcosa in un progetto

Fare un braccialetto

Coming back to OE exponent selection, the study on the semantics of the candidate verbs (ge)macian and (ge)dōn has determined that their meaning clearly differ from one another. Whereas (ge)macian (to make, do, produce, form, construct, arrange) presents a more restricted meaning which focuses on the resulting product and the process of the action, (ge)don (to do, make, act, perform) displays a general and more simple meaning to talk about actions. Therefore, it is (ge)dōn the verb selected as prime exponent of DO.

Furthermore, the competition between (ge)dōn and (ge)macian has called the attention of other authors such as Kuhn (1980), who dealt with the semantic overlapping of these two verbs within the Middle English period. This author remarks that both verbs have a common West Germanic origin; however, (ge) dōn was more common -and thus more available- in the OE lexicon than macian and gemacian, which were considered rare. Kuhn adds that, whereas attestations of (ge)dōn are found in all OE dialects, (ge)macian is only found in the West Saxon dialect and, indeed, there was no attestation of its use before the Alfredian period (1980: 5). Against this background, the selection of (ge) $d \bar{o} n$ as the OE exponent of DO is reinforced both by semantic and historical reasons.

All things considered, it is important to bare in mind that the NSM is a universal theory in the sense that semantic primes can be found cross-linguistically and they represent meanings existing in every natural language. However, the selection of semantic primes is language dependent. Hence, the different language specific semantic phenomena that may arise during the identification of primes should not be considered as a general rule or compared to one another, but primes should be studied within a particular cultural context.

\section{CONCLUSION}

This article aims at completing the exponent selection of the semantic primes included in the category Actions, events, movement, contact by establishing the OE exponent for the prime DO. With this purpose, the conclusion is drawn that the OE verb (ge)don is established as the OE exponent for the semantic prime DO. This research has proved that the results provided by (ge)dōn surpass those obtained by the rest of candidates, viz. (ge)pēon, (ge)drēogan and (ge)macian, in 
all the criteria analysed and fulfils the requirements proposed to be selected as the best prime exponent in this respect.

From a methodological point of view, this article has adopted the perspective of previous studies on this category by relying on an array of criteria to determine the adequacy of the candidate to be a proper prime exponent. However, the selection of candidates as prime exponents has entailed a change in methodology. At this point, etymological and grammatical arguments have given priority to one of the candidates over the others. For this reason, especial emphasis has been put on a single candidate, whose results obtained from the different criteria have been carefully contrasted to those of the rest of candidates to check its accuracy as prime exponent. This has allowed to narrow the scope of analysis and provide an in-depth description of the selected prime exponent.

This article has completed the line of research opened on the identification of semantic primes in OE within the category Actions, events, movement, contact. All these studies follow the same methodological principles, which converge on the analysis of candidates under a morphological, textual, semantic and syntactic perspective to determine their adequacy as prime exponents. However, within each study, the analysis has been continually improved and adapted to the requirements of each prime and, at the same time, it has been updated to the developments of the NSM theory. For instance, the research on HAPPEN revealed that some criteria are more conclusive than others (Mateo Mendaza 2016a). This is, the textual criterion is more sensitive to polysemy and homonymy, whereas the semantic and syntactic ones are more consistent given the semantic-syntactic basis of the NSM theory. Subsequent research made on the semantic prime MOVE, required an in-depth analysis on semantic-syntactic properties of the prime in order to restrict the selection of candidates to those verbs expressing motion in a transitive way (Mateo Mendaza 2016). And finally, the present study has also involved some modifications on candidate selection by using relevant literature to narrow the scope of analysis, establishing a single candidate as a benchmark for contrastive analysis.

All this confirms that the search for exponents for semantic primes in historical languages is not a straightforward task, but it needs to be continually refined and updated to the demands of each semantic prime and the novelties introduced by the researchers of the NSM theory. Nevertheless, the study carried out in this article, along with the results and discussion provided in previous research, allows us to establish the methodology proposed as the most effective process in the search for semantic primes in historical languages. In this sense, this approach lays the foundations of prime identification by validating the effectiveness of the criteria and by exposing the various issues that arise in this kind of analysis, as 
SEMANTIC PRIMES IN HISTORICAL LANGUAGES. THE IDENTIFICATION OF THE OLD ENGLISH..

well as potential solutions that can be applied to solve them. The studies on the category Actions, events, movement, contact altogether can be considered as a significant contribution to the NSM theory as they are the foundation for further research on semantic primes identification in other historical languages. Indeed, the selection of primes exponents in historical languages would undoubtedly benefit the assessment of the universal validity of the semantic primes and the NSM theory.

\section{REFERENCES}

Bauer, L. 2001. Morphological Productivity. Cambridge: Cambridge University Press Bosworth, J. and T. N. Toller. 1973 (1898). An Anglo-Saxon Dictionary. Oxford: Oxford University Press. Available online at: http://www.bosworthtoller.com.

de la Cruz Cabanillas, I. 2007. "Semantic Primes in Old English: a Preliminary Study of Descriptors”. SELIM 14: 37-58.

Denison, D. 1993. English Historical Syntax. New York: Longman Publishing.

Diamond, R. E. 1970. Old English Grammar and Reader. Detroit, Michigan: Wayne State University Press

Goddard, C. 1997. "The universal syntax of semantic primitives". Language Sciences 19 (3): 197-207.

Goddard, C., ed. 2008. Cross-Linguistics Semantics. Amsterdam / Philadelphia: John Benjamins Publishing Company.

Goddard, C. 2011. Semantic Analysis: A Practical Introduction. New York. Oxford University Press.

Goddard, C. 2012. "Semantic primes, semantic molecules, semantic templates: Key concepts in the NSM approach to lexical typology". Linguistics (Special issue on "Lexical Typology". Eds. M. Koptjevskaja-Tamm and M. Vanhove) 50 (3): 711-743.

Goddard, C. 2015. Verb classes and valency alternations (NSM approach), with special reference to English physical activity verbs. Eds. A. Malchukov and B. Comrie. Berlin: Mouton de Gruyter.

Goddard, C. 2019. "NSM webpage". http://www.une.edu.au/bcss/linguistics/nsm/ (Accessed 25 January 2019).

Goddard, C. and A. Wierzbicka, eds. 2002. Meaning and Universal Grammar. Theory and Empirical Findings, Volume 1. Amsterdam. John Benjamins.

Goddard, C. and A. Wierzbicka. 2016. "Explicating the English lexicon of "doing and happening". Functions of Language 23 (2): 214-256. 
Godden, M. 2016. The Old English History of the World: An Anglo-Saxon Rewriting of Orosius. Cambridge - MA - London: Harvard University Press.

Guarddon Anelo, M. C. 2009. "Un Análisis de las Propiedades Combinatorias de los Primitivos Semánticos a través de las Adposiciones Complejas en Inglés Antiguo". Revista Española de Lingüística 39 (2): 93-122.

Hall, J. R. C. 1996. A Concise Anglo-Saxon Dictionary. Toronto: Toronto University Press.

Healey diPaolo, A., Cameron, A., Crandell Amos, A. et al., eds. 2018. Dictionary of Old English: A to G online. Toronto. Dictionary of Old English Project.

Healey diPaolo, A., ed., with J. Price Wilkin and X. Xiang. 2009. The Dictionary of Old English Web Corpus. Toronto. Dictionary of Old English Project. Available at: http://www.doe.utoronto.ca/pub/webcorpus.htm.

Hogg, R. M. and R. D. Fulk. 2011. A Grammar of Old English (2 Volumes). United Kingdom: Wiley-Blackwell.

Kay, C., Roberts, J., Samuels, M. and I. Wotherspoon. 2009. The Historical Thesaurus of the Oxford English Dictionary. University of Glasgow: Oxford University Press.

Kuhn, S. M. 1980. "Middle English Don and Maken: Some Observations on Semantic Patterns". American Speech 52: 5-18.

Martín Arista, J. et al. 2009. Nerthus: An Online Lexical database of Old English. Available at: www.nerthusproject.com.

Martín Arista, J. and M. V. Martín de la Rosa. 2006. "Old English Semantic Primes: Substantives, Determiners and Quantifiers". ATLANTIS 28 (2): 9-28.

Mateo Mendaza, R. 2013. "The Old English exponent for the semantic prime TOUCH. Descriptive and methodological questions". Australian Journal of Linguistics 33 (4): 449-466.

Mateo Mendaza, R. 2016a. "The search for Old English semantic primes: the case of HAPPEN". Nordic Journal of English Studies 15 (1): 71-99.

Mateo Mendaza, R. 2016b. "The Old English exponent for the semantic prime MOVE". Australian Journal of Linguistics 36 (4): 542-55.

Miller, T. 1959a. Bede's Ecclesiastical History of the English People. Part I 1. LondonNew York-Toronto: Oxford University Press.

Miller, T. 1959b. Bede's Ecclesiastical History of the English People. Part I 2. LondonNew York-Toronto: Oxford University Press

Mitchell, B. 1985. Old English Syntax. Oxford: Oxford University Press.

Orel, V. 2003. A Handbook of Germanic Etymology. Leiden/Boston: Brill. 
Oxford University Press. 2020. Oxford Learner's Dictionary. Available at: www. oxfordlearnersdictionaries.com.

Quirk, R. and C. L. Wrenn. 1994 (1955). An Old English Grammar. DeKalb, Illinois: Northern Illinois University Press.

Ringe, D. and A. Taylor. 2014. The development of Old English. Oxford: Oxford University Press.

Roberts, J., Kay, C. and L. Grundy. 2000. A Thesaurus of Old English. AmsterdamAtlanta: Rodopi.

Royster, J. F. 1922. "Old English causative verbs". Studies in Philology 19: 328-356.

Skeat, W. W. 1993. The Concise Dictionary of English Etymology. Great Britain: Wordsworth.

Sweet, H. 1976 (1897). The Student's Dictionary of Anglo-Saxon. New York-London: The MacMillan Company.

Thorpe, B. 2011. The Homilies of the Anglo-Saxon Church. London: Richard and John E. Taylor.

Visser, F. T. 1984. An Historical Syntax of the English Language. Netherlands: E. J. Brill.

Wierzbicka, A. 1996. Semantics. Primes and Universals. Oxford: Oxford University Press. 